\title{
THERMODYNAMICS OF MICELLIZATION OF HEXADECYLTRIMETHYLAMMONIUM BROMIDE \\ IN PROPYLENE GLYCOL-WATER MIXTURE: A CONDUCTIVITY STUDY
}

UDC $[544.3: 532.74]: 544.62$

\author{
Aleksandra M. Janošević Ležaić, Nikola Paunović, Nataša Pejić \\ Department of Physical Chemistry and Instrumental Methods, Faculty of Pharmacy, \\ University of Belgrade, Serbia
}

\begin{abstract}
Micellization of hexadecyltrimethylammonium bromide (syn. cetyltrimethylammonium bromide, CTAB) in propylene glycol-water $(30 \% \mathrm{v} / \mathrm{v})$ binary mixture, as well as the thermodynamic properties of the resulting micelles, were investigated by electrical conductivity measurements. The conductivity data were used to determine both the critical micellar concentration $(C M C)$ and the micellar ionization degree $(\alpha)$ of CTAB in the temperature range 298.2-310.2 K. The equilibrium model of micelle formation was applied in order to obtain the thermodynamic parameters (the standard molar Gibbs free energy, $\Delta G_{m}{ }^{0}$, enthalpy, $\Delta H_{m}{ }^{0}$ and entropy, $\Delta S_{m}{ }^{0}$ ) of the micellization process. The values of $\Delta G_{m}{ }^{0}$ and $\Delta H_{m}{ }^{0}$ were found to be negative at all investigated temperatures, while the values of $\Delta S_{m}{ }^{0}$ were positive and became more positive as temperature increased. A linear dependence between $\Delta S_{m}{ }^{0}$ and $\Delta H_{m}{ }^{0}$, i.e. an enthalpy-entropy compensation effect, was observed.
\end{abstract}

Key words: hexadecyltrimethylammonium bromide, critical micellar concentration, propylene glycol-water mixture, thermodynamics of micellization, enthalpy-entropy compensation

\section{INTRODUCTION}

Surfactants are amphiphile molecules composed of two parts, one (polar; hydrophilic headgroup or liophobic segment) which is soluble in a specific polar solvent and the other (nonpolar; hydrophobic organic segment or lipophilic tail) that is insoluble. Based on the nature of their hydrophilic group-this is scientifically broadly accepted classificationsurfactants may be divided into three main groups: ionic (anionic and cationic), amphoteric and

Received March $06^{\text {th }}, 2014$; revised May $21^{\text {st }}, 2014$; accepted July $09^{\text {th }}, 2014$

Corresponding author: Aleksandra M. Janošević Ležaić

Department of Physical Chemistry and Instrumental Methods, Faculty of Pharmacy, University of Belgrade,

450 Vojvode Stepe Street, 11000 Belgrade, Serbia

E-mail: ajanosevic@yahoo.com 
nonionic $[1,2]$. In this work, we investigated cationic surfactant, hexadecyltrimethylammonium bromide (syn. cetyltrimethylammonium bromide, CTAB) (Fig. 1), which dissociated in water into cation of surfactant and bromide counterion. This surfactant is widely used as antiseptic, solubilizing agent for pharmaceuticals, in electrophoresis of proteins (for extraction of DNA), in hair conditioning products, and so forth.

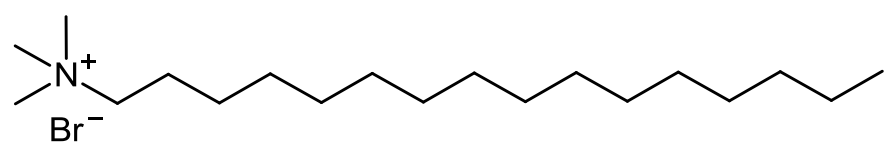

Fig. 1 Chemical structure of cetyltrimethylammonium bromide (CTAB)

Upon dispersion in water, and above the concentration known as the critical micelle concentration (CMC), the surfactants hydrophobic segment tend to minimize its exposure to solvent; due to this, molecules of surfactant self-associate to form aggregates (called micelles). Besides temperature, $\mathrm{pH}$ and pressure, the surfactant micelle formation in an aqueous solution is highly depend on presence of additives such as cosolvent, cosurfactants and electrolytes [2, 3]. Thus, much effort has been devoted to exploring nature of micellization and surfactant behavior in binary mixtures of organic solvent with water as well as in polar organic solvents (nonaqueous polar medium) [4-16].

Interfacial and micelle properties of surfactants in the presence of polar organic solvents, as cosolvents added to water, are modified due to both, cosolvent specific interactions with surfactant molecules, and modification of water-surfactant interaction (because of the changing of the balk solvent properties) [4-6]. Considering significant application of surfactants in nonaqueous media (as lubricants or cleaners), the investigation of cosolvent influence on micellar and physicochemical properties of surfactants has wide interests in both the fundamental as well as in the applied research [7, 8]. Because of their waterresembling like properties (high dielectric constant, a high cohesive energy and a significant hydrogen bonding ability), polar organic solvents such as formamide, ethylene glycol, glycerol, etc., have been studied extensively. The most common methodology used for studying micellization of various surfactants in water-organic solvent mixtures is based on gradual exchange of water for another (polar) solvent [5-14]. This methodology allows a simple characterization of the examined system (determination of structural properties of aggregates formed in those media, as well as revealing which properties the solvent should have in order to form micelle). On the other hand, in view of the fact that the micellar properties of surfactant sensitive to temperature changes, a lot of information on the strength and the nature of solvent-surfactant and solvent-solvent interactions can be obtained from the thermodynamic properties of micellization. These are also useful for uncovering (possible) relationship between solvophobic or hydrophobic effects $[4,15]$ and tendency of surfactant tails to minimize their contact with the bulk phase (water or organic solvent-water mixture) and aggregate.

Micellar properties and thermodynamic parameters of micelization of CTAB were investigated, both in aqueous media [12, 16-18], and in mixtures of water and various organic solvents such as $N$-methylacetamide, $N$-methylpropionamide, dimethyl sulfoxide, formamide, $N$-methylformamide, $N, N$-dimethylformamide [5, 16, 19], ethanol [12], propanol [20], butanol [20], glycerol [21, 22] and ethylene glycol [12, 15, 23]. A lot of effort has been made to investigate the effect of various glycols (e.g. propylene glycol, PG) on the 
surfactant aggregation and micellar properties since these solvents are widely used in different products (foods, pharmaceuticals, cosmetics and personal care products, etc.), whereby most of these products also contain surfactants. Recently, Rodríguez et al. [9], investigated the effects of various glycols on aggregation of tetradecyltrimethylammonium bromide. To our knowledge, however, no previous studies of the role of propylene glycol on the micellar characteristics of CTAB were carried out.

The aim of this work was to investigate the influence of temperature on the micellization process of CTAB in PG-water $(30 \% v / v)$ binary mixture. For this reason, we have carried out a series of conductivity measurements, in the temperature range 298.2-310.2 K. The CMC values and degree of micellar ionization $(\alpha)$ corresponding to each temperature were obtained from the conductivity data, and all were determined from inflections in plots of conductivity against surfactant concentration (William's method [24]). Also, to get more precise values of $\mathrm{CMC}$ and $\alpha$ we have applied method of Carpena et al. [25]. From the temperature dependence on $\mathrm{CMC}$ acquired by this method, and considering the equilibrium model for micelle formation, we have obtained the corresponding thermodynamic parameters of micellization (the standard molar Gibbs free energy $\left(\Delta \mathrm{G}_{\mathrm{m}}{ }^{0}\right)$, enthalpy $\left(\Delta \mathrm{H}_{\mathrm{m}}{ }^{0}\right)$ and entropy $\left(\Delta \mathrm{S}_{\mathrm{m}}{ }^{0}\right)$.

\section{MATERIALS AND METHODS}

\subsection{Chemicals}

The cationic surfactant, hexadecyltrimethylammonium (syn. cetyltrimethyl-ammonium bromide, CTAB; purity $\geq 97 \%$ ) was obtained by Merck (Germany) and was used without any pretreatment. Propylene glycol, PG (1,2-propylene glycol, purity $>99,5 \%)$ was obtained by Carlo Erba (Italy). Deionized water ( $\rho=18 \mathrm{M} \Omega \mathrm{cm}$, Milli-Q, Millipore, Bedford, MA, USA) was used for all solutions preparing.

Fresh solutions of CTAB in PG-water $(30 \% v / v)$ binary mixtures were prepared in the following way. The accurately weighed (Mettler electronic balance with a precession of $0.0001 \mathrm{~g}$ ) mass of CTAB was quantitatively transferred into a $100 \mathrm{~mL}$ volumetric beaker, and dissolved in $90 \mathrm{~mL}$ of $30 \%(\mathrm{v} / \mathrm{v})$ PG; the mixture was gently stirred with a glass rod in order to avoid the foam formation. Then, the solution was transferred into $100 \mathrm{~mL}$ volumetric flask and made up to volume with $30 \%(v / v)$ PG.

\subsection{Apparatus}

The conductivity measurements were carried out with digital conductivity meter HI8820N (Hanna instruments, Portugal) with the accuracy $\pm 0.5 \%$, and with the matching HI7684W probe that uses the 4-ring method. Specific conductivity values of each set containing 18 different $\mathrm{CTAB}$ concentrations at a fixed solvent composition were taken at different working temperatures (298.2, 302.2, 306.2 and $310.2 \mathrm{~K})$. A circulating water bath (Series U, MLW, Frietal, Germany) was used for maintaining the constant temperature within uncertainties of \pm $0.1 \mathrm{~K}$.

All measurements were conducted in glass vessel, $\mathrm{V} \approx 100 \mathrm{~mL}$ (Metrohm Model 876-20) wrapped in the water recirculation jacked connected to thermostat and equipped with the magnetic stirrer (IKA-COMBIMAG RET, Staufen, Germany). 


\subsection{Procedure}

The $90 \mathrm{~mL}$ solution of CTAB of different concentrations was introduced into the glass vessel that was capped with openings through which thermometer and conductometric cell are always put in the same place. Then, CTAB solution was thermostated (20 min) at some of the examined temperatures $(298.2,302.2,306.2$ and $310.2 \mathrm{~K}$ ) along with stirring (300 $\mathrm{rpm})$, and equilibrated until the conductivity value becomes constant. For each of the examined solution $\mathrm{CTAB}$, the specific conductivity measurements were repeated three times.

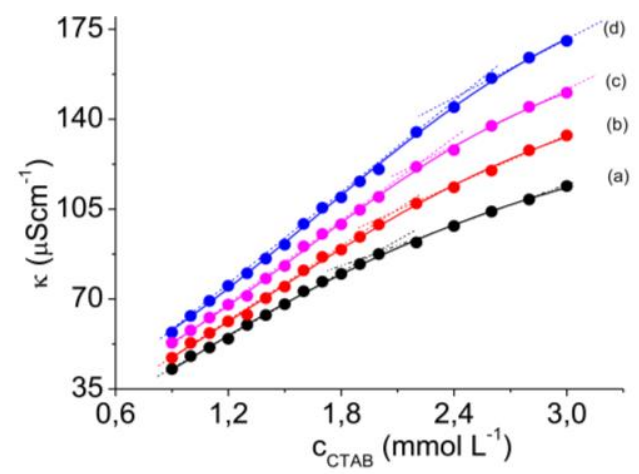

Fig. 2 Plots of specific conductivity $(\kappa)$ versus total concentration of CTAB $\left(\mathrm{c}_{\mathrm{CTAB}}\right)$ in PG-water mixture $(30 \%(v / v)$ at different temperatures: $298.2 \mathrm{~K}(\mathrm{a}), 302.2 \mathrm{~K}(\mathrm{~b})$, $306.2 \mathrm{~K}(\mathrm{c})$ and $310.2 \mathrm{~K}(\mathrm{~d})$. At each temperature, the solid line corresponds to the Carpena's fitting

The data points above and below the inflection were fit by the least square method (correlation coefficients were greater than 0.999 in all cases) to two equations of the form: $\kappa$ $=\mathrm{A}+\mathrm{S} \times \mathrm{c}_{\mathrm{CTAB}}$, and by two equation solving, the point of intersection $(\mathrm{CMC})$ was obtained $[23,24,26]$. The obtained values of the CMC of CTAB as well as slopes below $\left(\mathrm{S}_{1}\right)$ and above $\left(\mathrm{S}_{2}\right)$ the $\mathrm{CMC}$ in the conductivity-concentration plots at different temperatures, are all summarized in Table 1.

\section{RESULTS AND DISCUSSION}

\subsection{Critical micellar concentration (CMC) and micelle ionization degree $(\alpha)$}

The CMC value of CTAB in PG-water $(30 \% v / v)$ binary mixture was determined from inflection in plot of specific conductivity, $\kappa$ against concentration of CTAB, $\mathrm{c}_{\mathrm{CTAB}}$. Representative plots, $\kappa=\mathrm{f}\left(\mathrm{c}_{\mathrm{CTAB}}\right)$ at different temperatures, $298.2 \mathrm{~K}, 302.2 \mathrm{~K}, 306.2 \mathrm{~K}$ and $310.2 \mathrm{~K}$ are shown in Figure 2. The obtained graphical dependence is a curve which consists of two segments (premicellar and postmicellar); each plot shows the single break point at a certain temperature. 
Table 1 Critical micellar concentration (CMC), slopes of lines in both premicellar $\left(\mathrm{S}_{1}\right)$ and posmicellar $\left(\mathrm{S}_{2}\right)$ region and micellar ionization degrees of CTAB in mixture propylene glycol-water $(30 \%(v / v)$ at different temperatures. The values given in parentheses obtained by method of Carpena et al. [25].

\begin{tabular}{ccccc}
\hline $\begin{array}{c}\mathrm{T} \\
(\mathrm{K})\end{array}$ & $\begin{array}{c}\mathrm{CMC} \\
\left(\mathrm{mmol} \mathrm{L}^{-1}\right)\end{array}$ & $\begin{array}{c}\mathrm{S}_{1} \\
\left(\mu \mathrm{S} \mathrm{dm}^{2} \mathrm{~mol}^{-1}\right)\end{array}$ & $\begin{array}{c}\mathrm{S}_{2} \\
\left(\mu \mathrm{Sm}^{2} \mathrm{~mol}^{-1}\right)\end{array}$ & $\alpha$ \\
\hline 298.2 & 1.91 & 41.336 & 26.928 & 0.651 \\
& $(1.85)$ & $(43.069)$ & $(27.145)$ & $(0.630)$ \\
302.2 & 2.03 & 48.164 & 35.400 & 0.735 \\
& $(2.09)$ & $(48.795)$ & $(31.472)$ & $(0.645)$ \\
306.2 & 2.21 & 52.450 & 42.000 & 0.801 \\
& $(2.38)$ & $(51.536)$ & $(32.519)$ & $(0.631)$ \\
310.2 & 2.43 & 58.300 & 49.700 & 0.852 \\
& $(2.63)$ & $(57.318)$ & $(35.480)$ & $(0.619)$ \\
\hline
\end{tabular}

The micellar ionization degree $(\alpha)$ was estimated from the ratio of the slopes of the linear segments above and below CMC: $\alpha=\mathrm{S}_{2} / \mathrm{S}_{1}$ [27]. The values of $\alpha$ at various temperatures are summarized in Table 1.

Besides the above-described "conventional procedure" (William's method [24]) for the $\mathrm{CMC}$ and $\alpha$ determination, in order to find out precise CMC values from conductivity data, different fitting procedures to the experimental data have also been applied [25, 26]. Thus, in order to improve quality of the calculated CMC and $\alpha$, the method proposed by Carpena et al. [25] was used. This method is based on the fit of the experimental raw data to a simple nonlinear function obtained by direct integration of Boltzmann type sigmoid function. Fitting to the data was carried out by Origin software (Origin version 8.0.). The solid lines (Fig. 2) correspond to the Carpena's fitting. The values of the CMC and $\alpha$ obtained by this approach are listed in Table 1. Obviously, these values, as well as the values of the CMC and $\alpha$, obtained by "conventional procedure" appear to be in good agreement at temperatures $298.2 \mathrm{~K}$ and $302.2 \mathrm{~K}$, that cannot be said for the other two temperatures. For thermodynamic calculations, temperature dependences of the $\mathrm{CMC}$ and $\alpha$ obtained by Carpena's method were used.

The attained values of CMC of CTAB in PG-water mixture (Table 1) are higher than those obtained for CTAB in water [12, 16-18], at a constant temperature. Previously, an increase in the CMC values of different surfactants upon the addition of various solvents [5, $10-12,14,16,19,22]$ was acquired. This behavior was found for organic solvents whose presence either increases or decreases the permittivity of the bulk phase, and can only be explained if one takes into account a number of factors that affect the micellization process, such as solvent polarity, solvent interaction, solvophobic forces, etc.

For the examined system in selected temperature range, the values of CMC increased with temperature, while values of $\alpha$ slightly changed (Table 1). Generally, the effect of temperature on CMC in aqueous solution may be explained by temperature influence on the degree of hydration of the hydrophilic groups, which decreases with an increase of temperature (this favors micellization). The opposite effect (unfavorable for micellization) is disruption of water structure surrounding the hydrophobic surfactant group, which occurs at higher temperatures $[5,11,12]$. From the obtained results (Table 1) it seems that this second effect is predominant in the studied temperature range. 


\subsection{Thermodynamic properties}

In order to quantify how addition of PG affects the micellization of CTAB, the standard molar Gibbs free energy, enthalpy and entropy of micellization were calculated by means of the equilibrium model for the micelle formation [28], and temperature dependence of CMC.

The change of the standard molar Gibbs free energy, $\Delta \mathrm{G}_{\mathrm{m}}{ }^{0}$ was calculated by using the following equation:

$$
\Delta \mathrm{G}_{\mathrm{m}}^{0}=(2-\alpha) \mathrm{RT} \ln \mathrm{X}_{\mathrm{CMC}}
$$

where $\alpha$ is the micellar ionization degree, $\mathrm{R}$ is the gas constant, $\mathrm{T}$ is the Kelvin temperature, and $\mathrm{X}$ is the value of $\mathrm{CMC}$ expressed in the mole fraction unit [2]. For this calculations, values of the CMC and $\alpha$ obtained by Carpena's method were used.

The corresponding standard molar enthalpy, $\Delta \mathrm{H}_{\mathrm{m}}{ }^{0}$ is given by [2]:

$$
\Delta \mathrm{H}_{\mathrm{m}}^{0}=-\mathrm{RT}^{2}\left[(2-\alpha)\left(\frac{\partial \ln \mathrm{X}_{\mathrm{CMC}}}{\partial \mathrm{T}}\right)_{\mathrm{p}}-\ln \mathrm{X}_{\mathrm{CMC}}\left(\frac{\partial \alpha}{\partial \mathrm{T}}\right)_{\mathrm{p}}\right]
$$

The changes of standard molar enthalpy of micellization, $\Delta \mathrm{H}_{\mathrm{m}}{ }^{0}$ may be obtained from equation (2), if the dependences of the $\ln \mathrm{X}_{\mathrm{CMC}}$ as well as $\alpha$ on temperature are known. With this purpose, $\ln \mathrm{X}_{\mathrm{CMC}}$ was plotted against $\mathrm{T}$, and the slope at each temperature was taken as $\left(\frac{\partial \ln X_{C M C}}{\partial T}\right)_{p}$. The obtained dependence, $\ln X_{C M C}=f(T)$, is polynomial $\left(r^{2}=0.9989\right)$. Note that second term in equation (2) can be neglected due to the fact that values of $\alpha$ vary slightly with temperature.

The change of the standard molar entropy, $\Delta \mathrm{S}_{\mathrm{m}}{ }^{0}$ was calculated from equation:

$$
\Delta \mathrm{S}_{\mathrm{m}}^{0}=\frac{\Delta \mathrm{H}_{\mathrm{m}}^{0}-\Delta \mathrm{G}_{\mathrm{m}}^{0}}{\mathrm{~T}}
$$

Thermodynamic parameters of CTAB micellization $\left(\Delta \mathrm{G}_{\mathrm{m}}{ }^{0}, \Delta \mathrm{H}_{\mathrm{m}}{ }^{0}\right.$ and $\left.\Delta \mathrm{S}_{\mathrm{m}}{ }^{0}\right)$ at different temperatures $(298.2 \mathrm{~K}, 302.2 \mathrm{~K}, 306.2 \mathrm{~K}$ and $310.2 \mathrm{~K}$ ) obtained from equations (1)-(3), are listed in Table 2 .

Table 2 Thermodynamic parameters of micellization of CTAB in mixture propylene glycol-water $(30 \%(v / v))$ at different temperatures

\begin{tabular}{lcccc}
\hline Thermodynamic & \multicolumn{4}{c}{ Temperature $(\mathrm{K})$} \\
\cline { 2 - 5 } parameter & 298.2 & 302.2 & 306.2 & 310.2 \\
\hline$\Delta \mathrm{G}_{\mathrm{m}}^{0}\left(\mathrm{~kJ} \mathrm{~mol}^{-1}\right)$ & -35.02 & -34.68 & -35.06 & -35.47 \\
$\Delta \mathrm{H}_{\mathrm{m}}^{0}\left(\mathrm{~kJ} \mathrm{~mol}^{-1}\right)$ & -34.44 & -32.10 & -30.42 & -28.39 \\
$\Delta \mathrm{S}_{\mathrm{m}}^{0}\left(\mathrm{~kJ} \mathrm{~mol}^{-1} \mathrm{~K}^{-1}\right)$ & 0.0019 & 0.0086 & 0.0151 & 0.0228 \\
$\mathrm{~T} \Delta \mathrm{S}_{\mathrm{m}}^{0}\left(\mathrm{~kJ} \mathrm{~mol}^{-1}\right)$ & 0.578 & 2.585 & 4.639 & 7.072 \\
\hline
\end{tabular}


The value of $\Delta \mathrm{G}_{\mathrm{m}}{ }^{0}$ was negative at all the considered temperatures (the micellization process is spontaneous), and slightly changes (Table 2) in the investigated temperature range. The value of $\Delta \mathrm{H}_{\mathrm{m}}{ }^{0}$ was negative at all temperatures (the micellization process is exothermic), and becomes less negative as the temperature increases.

In the micellar process of different surfactants, the so-called enthalpy-entropy compensation was obtained [11, 29-31]. This phenomenon reflects a linear correlation between enthalpy and entropy change. For CTAB, such enthalpy-entropy compensation effect was reported for micellization of this surfactant in polar nonaqueous solvents ( $N$-methylacetamide, $N, N$ dimethylformamide, formamide and dimethyl sulfoxide) [16]. The slope of compensation line is termed as compensation temperature, $T_{c}$ [29]. The compensation plot obtained for CTAB in studied PG-water binary mixture is shown in Fig. 3. This curve obeys the following linear regression equation: $\Delta \mathrm{H}_{\mathrm{m}}{ }^{0}=-34.8+286.0 \times \Delta \mathrm{S}_{\mathrm{m}}{ }^{0}\left(\mathrm{r}^{2}=0.997\right)$. At around $\Delta \mathrm{S}_{\mathrm{m}}{ }^{0}$ value of 0.12 $\mathrm{kJ} \mathrm{mol}^{-1} \mathrm{~K}^{-1}, \Delta \mathrm{H}_{\mathrm{m}}{ }^{0}$ becomes zero, and CTAB interaction in this condition is favored only by entropy change. The obtained $\mathrm{T}_{\mathrm{c}}$ is $286.05 \mathrm{~K}$. At this temperature the micellization of CTAB is totally independent of structure changes of the system and it depends on the enthalpic forces.

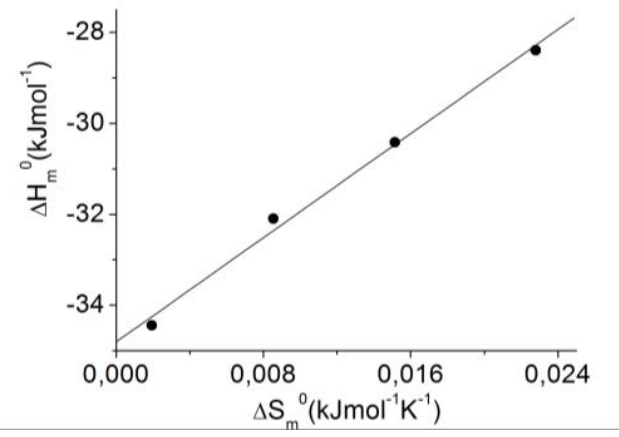

Fig. 3 Enthalpy-entropy compensation plot

In addition, the effect of $\mathrm{PG}$ on $\mathrm{CTAB}$ micellization can be also discussed through socalled free energy of transfer, $\Delta \mathrm{G}_{\mathrm{T}}^{0}=\left(\Delta \mathrm{G}_{\mathrm{m}}^{0}\right)_{\mathrm{PG}+\mathrm{H}_{2} \mathrm{O}}-\left(\Delta \mathrm{G}_{\mathrm{m}}^{0}\right)_{\mathrm{H}_{2} \mathrm{O}}$ [32], where $\left(\Delta \mathrm{G}_{\mathrm{m}}^{0}\right)_{\mathrm{PG}+\mathrm{H}_{2} \mathrm{O}}$ and $\left(\Delta \mathrm{G}_{\mathrm{m}}^{0}\right)_{\mathrm{H}_{2} \mathrm{O}}$ are changes of standard molar Gibbs free energy of CTAB micellization in $\mathrm{PG}$-water mixture and water, respectively. For this calculation, values of $\left(\Delta \mathrm{G}_{\mathrm{m}}^{0}\right)_{\mathrm{H}_{2} \mathrm{O}}$ are taken from literature [12]. At certain temperature, $\left(\Delta \mathrm{G}_{\mathrm{m}}^{0}\right)_{\mathrm{PG}+\mathrm{H}_{2} \mathrm{O}}$ is: $12.48 \mathrm{~kJ} \mathrm{~mol}^{-1}$ $(298.2 \mathrm{~K}), 12.82 \mathrm{~kJ} \mathrm{~mol}^{-1}(302.2 \mathrm{~K}), 12.41 \mathrm{~kJ} \mathrm{~mol}^{-1}$ (306.2) and $12.22 \mathrm{~kJ} \mathrm{~mol}^{-1}$ (310.2 $\mathrm{K})$. The obtained values are positive at all investigated temperatures. Rodríguez et al. [5] have pointed out that organic solvent addition results in the bulk phase that is becoming a better solvent for the surfactant molecules. This would make the hydrophobic tail transfer from the bulk phase into the micelle less favorable. As a result of this increase in the solubility of hydrophobic tails, there is also an increase in the CMC. This fact can explain the obtained experimental results in a qualitative way. Thus, the positive values of the obtained $\Delta \mathrm{G}_{\mathrm{T}}{ }^{0}$, in the presence of PG in the solvent system, indicate that the presence of PG causes increasing of CTAB hydrocarbon tails solubility, and decreasing of the solvophobic effect. Similar behavior has been obtained previously for micellization of tetradecyltrimethylammonium bromide in ethylene glycol-water binary mixture [11]. 


\section{CONCLUSIONS}

From the obtained results it is possible to reach the following conclusions:

a) The obtained values of CMC of CTAB in the examined system (PG-water $(30 \%$ $v / v)$ binary mixture) are higher than the values obtained in water [12, 16-18]. So, the micelization was inhibited by this additive.

b) The values of CMC of CTAB in the examined system increase with temperature. It seems clear that the effect of breaking the water structure surrounding the hydrophobic groups is dominant in the studied temperature range.

c) The micellization process is spontaneous $\left(\Delta \mathrm{G}_{\mathrm{m}}{ }^{0}<0\right)$ and exothermic $\left(\Delta \mathrm{H}_{\mathrm{m}}{ }^{0}<0\right)$ at all the examined temperatures.

d) At the temperature $286.05 \mathrm{~K}$, micellization of CTAB in presence of $30 \% \mathrm{PG}$ in binary mixture (with water) is totally independent of structure changes of the system and it depends on the enthalpic forces.

e) The calculated $\Delta \mathrm{G}_{\mathrm{T}}{ }^{0}$ values are positive at all temperatures. This implies that addition of PG causes the increase of CTAB hydrocarbon tails solubility as well as decrease of the solvophobic effect, and consequently an increase of the CMC.

Acknowledgement. The present investigations were partially supported by The Ministry of Education, Science and Technological Development of Serbia, under Project 172015.

\section{REFERENCES}

1. Lj. Đaković, Koloidna hemija, Zavod za udžbenike i nastavna sredstva, Beograd, 2006.

2. M.J. Rosen, Surfactants and interfacial phenomena, $3^{\text {th }}$ ed., John Wiley \& Sons, New York, 2004

3. J.H. Klient, Surfactant aggregation, Chapman \& Hall, New York, 1991.

4. R. Palepu, H. Gharibi, D. Bloor and E. Wyn-Jones, Electrochemical studies associated with the micellization of cationic surfactants in aqueous mixtures of ethylene glycol and glycerol, Langmuir, 9 (1), 110-112 (1993).

5. A. Rodríguez, M.M. Graciani and M.L. Moyá, Effects of addition of polar organic solvents on micellization, Langmuir, 24 (22), 12785-12792 (2008).

6. S. Das, S. Mondal and S. Ghosh, Physicochemical studies on the micellization of cationic, anionic, and nonionic surfactants in water-polar organic solvent mixtures, Journal of Chemical \& Engineering Data, 58 (9), 2586-2595 (2013).

7. Y.S. Lee and K.W. Woo, Micellization of aqueous cationic surfactant solutions at the micellar structure transition concentration-based upon the concept pseudophase separation, Journal of Colloid and Interface Science 169 (1), 34-38 (1995).

8. A. Rodríguez, M.M. Graciani and M.L. Moyá, Effects of organic solvent addition on the aggregation and micellar growth of cationic dimeric surfactant 12-3-12,2Br, Langmuir, 23 (23), 11496-11505 (2007).

9. A. Rodríguez, M.M. Graciani, G. Fernández and M.L. Moyá, Effects of glycols on the thermodynamic and micellar properties of TTAB in water, Journal of Colloid and Interface Science, 338 (1), 207-215 (2009).

10. S. Kolay, K.K. Ghosh, A. MacDonald, J. Moulins and R.M. Palepu, Micellization of alkyltriphenylphosphonium bromides in ethylene glycol and diethylene glycol + water mixtures: thermodynamic and kinetic investigation, Journal of Solution Chemistry, 37 (1), 59-72 (2008).

11. C.C. Ruiz, Thermodynamics of micellization of tetradecyltrimethylammonium bromide in ethylene glycolıwater binary mixtures, Colloid and Polymer Science, 277 (7), $701-707$ (1999).

12. H. Akbaş and Ç. Kartal, Conductometric studies of hexadecyltrimethylammonium bromide in aqueous solutions of ethanol and ethylene glycol, Colloid Journal, 68 (2), 125-130 (2006).

13. M.S. Bakshi and G. Kaur, Effects of glycol additives on the mixed micelle formation by hexadecyltrimethylammonium bromide + dodecylpyridinium chloride mixtures, Journal of Molecular Liquids, 88 (1), 15-32 (2000). 
14. A. Shrivastava and K.K. Ghosh, Micellization of cetyl triphenyl phosphonium bromide surfactant in binary aqueous solvents, Journal of Surfactants and Detergents, 11 (4), 287-292 (2008).

15. M.L. Moyá, A. Rodríguez, M.M. Graciani and G. Fernández, Role of the solvophobic effect on micellization, Journal of Colloid and Interface Science, 316 (2), 787-795 (2007).

16. H.N. Singh, S.M. Saleem, R.P. Singh and K.S. Birdi, Micelle formation of ionic surfactants in polar nonaqueous solvents, Journal of Physical Chemistry, 84 (17), 2191-2194 (1980).

17. S. Paredes, M. Tribout and L. Sepulveda, Enthalpies of micellization of the quaternary tetradecyl- and cetyltrimethylammonium, Journal of Physical Chemistry, 88 (9), 1871-1875 (1984).

18. N. Jiang, P. Li, Y. Wang, J. Wang, H. Yan and R. Thomas, Aggregation behavior of hexadecyltrimethylammonium surfactants with various counterions in aqueous solution, Journal of Colloid and Interface Science, 286 (2), 755-760 (2005)

19. M. Sjoeberg, U. Henriksson and T. Waernheim, Deuteron nuclear magnetic relaxation of $[1,1-2 \mathrm{H}]$ hexadecyltrimethylammonium bromide in micellar solutions of nonaqueous polar solvents and their mixtures with water, Langmuir, 6 (7), 1205-1211 (1990)

20. I. Benito, M.A. Garcia, C. Monge, J.M. Saz and M.L. Marina, Spectrophotometric and conductimetric determination of the critical micellar concentration of sodium dodecyl sulfate and cetyltrimethylammonium bromide micellar systems modified by alcohols and salts, Colloids and Surfaces, 125 (2-3), 221-224 (1997).

21. G. D'Errico, D. Ciccarelli and O Ortona, Effect of glycerol on micellar formation by ionic and nonionic surfactants at $25^{\circ} \mathrm{C}$, Journal of Colloid and Interface Science, 286 (2), 747-754 (2005).

22. P.K. Sansanwal, Effect of co-solutes on the physico-chemical properties of surfactant solutions, Journal of Scientific \& Industrial Research, 65 (1), 57-64 (2006).

23. A. Rodríguez, M.M. Graciani, M. Muñoz and M.L. Moyá, Water-ethylene glycol alkyltrimethylammonium bromide micellar solutions as reaction media: study of spontaneous hydrolysis of phenyl chloroformate, Langmuir, 19 (18), 7206-7213 (2003).

24. R.J. Williams, J.N. Phillips and K.J. Mysels, The critical micellar concentration of sodium lauryl sulphate at $25^{\circ} \mathrm{C}$, Transactions of the Faraday Society, 51 (16), 728-737 (1955).

25. P. Carpena, J. Aguiar, P. Bernaola-Galván and C. Carnero Ruiz, Problems associated with the treatment of conductivity-concentration data in surfactant solutions: simulations and experiments, Langmuir, 18 (16), 6054-6058 (2002).

26. M. Pérez-Rodríguez, G. Prieto, C. Rega, L.M. Varela, F. Sarmiento and V. Mosquera, A comparative study of the determination of the critical micelle concentration by conductivity and dielectric constant measurements, Langmuir, 14 (16), 4422-4426 (1998).

27. P. Lianos and J. Lang, Static and dynamic properties of sodium p-(1-propylnonyl)benzenesulfonate micelles, Journal of Colloid and Interface Science, 96 (1), 222-228 (1983).

28. D.F. Evans and H. Wenneström, The Colloidal Domain: Where Physics, Chemistry Biology Meets, Wiley-VCH, New York, 1994.

29. G. Sugihara and M. Hisatomi, Enthalpy-entropy compensation phenomenon observed for different surfactants in aqueous solution, Journal Colloid and Interface Science, 219 (1), 31-36 (1999).

30. S.B. Sulthana, S.G.T. Bhat and A.K. Rakshit, Thermodynamics of micellization of a non-ionic surfactant Myrj 45: effect of additives, Colloids and Surfaces A: Physicochemical and Engineering Aspects, 111 (1-2), 57-65 (1996).

31. B. Sharma and A.K. Rakshit, Thermodynamics of micellization of a nonionic surfactant: Brij 35 in aquo-sucrose solution, Journal of Colloid and Interface Science, 129(1), 139-144 (1989).

32. D. Atwood and A.T. Florence, Surfactants systems: Their Chemistry, Pharmacy and Biology, Chapman \& Hall, New York, 1983. 


\section{TERMODINAMIKA MICELIZACIJE HEKSADECILTRIMETILAMONIJUM-BROMIDA \\ U SMEŠI PROPILEN-GLIKOL-VODA: KONDUKTOMETRIJSKO ISPITIVANJE}

Konduktometrijski je ispitivana micelizacija heksadeciltrimetilamonijum-bromida (sinonim cetiltrimetilamonijum-bromid, CTAB) u binarnoj smeši propilen-glikol-voda $(30 \%, v / v)$, kao $i$ termodinamičke osobine nastalih micela. Merenjem specifične provodljivosti određeni su kritična micelarna koncentracija (KMK) $i$ stepen jonizacije micele $(\alpha)$ CTAB u opsegu temperatura 298,2-310,2 K određeni su. Primenom ravnotežnog modela za proces micelizacije izračunati su termodinamički parametri: promena standardne molarne Džibsove slobodne energije, $\left(\Delta G_{m}{ }^{0}\right)$, entalpije $\left(\Delta H_{m}{ }^{0}\right)$ i entropije $\left(\Delta S_{m}{ }^{0}\right)$ micelizacije. Vrednosti $\Delta G_{m}{ }^{0} i \Delta H_{m}{ }^{0}$ su bile negativne na svakoj od ispitivanih temperatura, dok su vrednosti $\Delta S_{m}{ }^{0}$ bile pozitivne i povećavale su se sa porastom temperature. Na osnovu linearne zavisnosti između $\Delta H_{m}{ }^{0} i \Delta S_{m}{ }^{0}$ utvrđen je tzv. entalpijskoentropijski kompenzacioni efekat.

Ključne reči: heksadeciltrimetilamonijum-bromid, smeša propilen-glikol-voda, termodinamika micelizacije, kritična micelarna koncentracija, termodinamika micelizacije, entalpijsko-entropijska kompenzacija 